UDC 378: 373.2.011.3-051

\author{
Roman S. Gurevych \\ Doctor of Pedagogical Sciences, Professor, Academician of the National Academy of Educational Sciences of \\ Ukraine, Director of the Educational and Scientific Institute of Pedagogy, Psychology, Training of Specialists of \\ Higher Qualification \\ Vinnytsia State Pedagogical University named after Mykhailo Kotsiubynskyi,Vinnytsia, Ukraine \\ ORCID ID 0000-0003-1304-3870 \\ imadvdpu@gmail.com
}

\author{
Oksana O. Rogulska \\ $\mathrm{PhD}$ of Pedagogical Sciences, Associate Professor, Department of Foreign Languages Practice and Teaching \\ Methodology Khmelnytskyi National University, Khmelnytskyi, Ukraine \\ ORCID ID 0000-0001-5603-0274 \\ oxana.rogulska@gmail.com
}

Olha V. Tarasova

PhD of Pedagogical Sciences, Associate Professor, Department of Foreign Languages Practice and Teaching Methodology Khmelnytskyi National University, Khmelnytskyi, Ukraine

ORCID ID 0000-0001-8574-6466

tarasova20olia@gmail.com

Olha V. Magdiuk

PhD of Pedagogical Sciences, Associate Professor, Department of Foreign Languages Practice and Teaching Methodology Khmelnytskyi National University, Khmelnytskyi, Ukraine

ORCID ID 0000-0001-6165-6386

olga-tychinska@rambler.ru

\title{
A MODEL OF FOREIGN LANGUAGE TEACHERS TRAINING IN THE INFORMATION-EDUCATIONAL ENVIRONMENT OF HIGHER EDUCATIONAL INSTITUTIONS
}

\begin{abstract}
The article addresses the expediency of creating and maintaining informationeducational environment at higher educational institutions. The views of scholars on the definition of the "information- educational environment of higher educational institutions" are analyzed. The information-educational environment of Khmelnytskyi National University is described and the peculiarities of the future foreign language teachers training in the conditions of the informationeducational environment of higher educational institutions are revealed. It is proved that the information-educational environment has considerable potential for improving the quality of education of the future foreign language teachers. It promotes students' awareness of the specifics of their future professional activities, develops personal and professional qualities necessary for their future career; gives the possibility to construct individual educational paths and develop students' creative abilities. A model of the future foreign language teachers training system in the conditions of the information- educational environment of higher educational institutions is theoretically grounded. The model contains the following blocks: target; theoretical and methodological; content and technological; control-productive. The target block of the model reveals the purpose of training and social requirements for a competitive future foreign language teacher. The target block generates other elements of the model necessary to achieve the expected result. The theoretical and methodological block includes the fundamentals of the concept of the future foreign language teachers training for professional activities; methodological approaches, didactic and specific principles. The content and technological block contains organizational and pedagogical conditions describing the main methods and forms of professional training, means and technologies for its implementation. The educational content of the model includes: compulsory and elective courses of the curriculum and practical training sessions aimed at the professional training of the future foreign language teachers. The other element of the model is the identification of stages of its implementation: theoretical and practical, correction and stabilization, reflexive and fixing. The control-productive block determines the formation of components that ensure the readiness of the future foreign language teachers for professional activity (motivational and axiological, cognitive and communicative, pragmatic and practical,
\end{abstract}


functional and personal, evaluative and reflexive), criteria (motivational, educational, operational, personal, reflexive) and levels(low (reproductive), middle (productive) or high (professional).

Keywords: foreign language teachers training; electronic educational resources; informationeducational environment; higher educational institutions; model of the system.

\section{INTRODUCTION}

Statement of the problem. Ukraine, having clearly opted for European integration, is modernizing its educational system in the context of European requirements. The emphasis is placed on the quality of education, the competitiveness of university graduates and the international prestige of Ukrainian higher education. Foreign language teaching is one of the priority directions of the education reform. The introduction of the concept of "The New Ukrainian School" accelerates the state policy reformation of the secondary education for the period up to 2029. The concept raises the issue of the foreign language teachers' training quality. This document explains an ideology of changes introduced in the new Draft Law "On Education" (No. 3491-d of 04/04/2016). This Draft Law was a result of the socio-political dialogue that lasted for more than 3 years. According to experts, in the short-term perspective, professionals who are able to learn throughout life, think critically, set and achieve goals, work in teams, communicate in a multicultural environment and possess other contemporary skills, will be the most successful in the labour market. The New Draft Framework Education Law of Ukraine states that the goal of the complete general secondary education is comprehensive development, education and formation of individuals who perceive themselves as citizens of Ukraine, capable of living in the society and interacting with nature in a civilized way, aspire for self-perfection and life-long study, and ready for the creative self-realization and community involvement [11]. The key elements of "The New Ukrainian School" are the following: 1) new educational content based on enabling the competencies necessary for successful self-fulfillment in society; 2) motivated teaching staff who enjoy freedom of creativity and professional development; 3) a cross-cutting educational process that in stills values; 4) decentralization and effective administration that will bring real autonomy to schools; 5) teaching based on partnerships between the pupil, the teacher and the parents; 6) a focus on pupil's needs in the educational process, i.e. child-centered education; 7) a new school structure that allows mastering the new content and acquiring life competencies; 8) fair allocation of public funds that ensures equal access to quality education for all children; 9) a contemporary educational environment that will provide necessary conditions, means, and technology for education of pupils, teachers, and parents, not only on the premises of the educational establishment [19]. The conceptual principles of Secondary School Reform also include the extensive use of ICT in the educational process and management of educational institutions. The official documents emphasize that the introduction of ICT in education should move beyond isolated ventures to a systematic drive that covers all activities. ICT will significantly expand teacher's capabilities and optimize management processes, instilling technology competencies in pupils [19].

We fully agree with $\mathrm{M}$. Zhaldak, whoaffirms that the principal purpose of informatization of the educational system is to increase the efficiency of education by expanding the amount of information and improving the methods of its application, as well as to focus on the possibility of the information technology application in the educational process of the higher educational institutions and the students' future professional activities [21, p. 145].C. Abbott states that it is now abundantly clear that the development of information and communication technologies is very different. Schooling and teaching will be forced to change in a variety of ways. At one level we now have to teach computer skills, not 
least because career prospects for our students may be dependent on the possession of such skills. Second, we have to prepare students for a society in which many traditional aspects of living have been transformed, aspects which include retailing, banking and communication by means such as e-mail [1, p. 21]. Another argument for the inclusion of ICT is that it has the potential to encourage and support the kinds of activities associated with the new learning emphasis of the 21st century [7, p. 7].

The informational technologies are the basis for restructuring the educational process under the conditions of the credit-module system, creating new opportunities, and at the same time, putting forward new requirements for their effective use in the educational environment of higher educational institutions. Scholars emphasize that the more diverse informationeducational environment is, the more effective learning process will be, taking into consideration the individual skills and abilities of students, their interests, subjective experience and background knowledge.

Analysis of recent research and publications. Theoretical aspects of training foreign language teachers are the subject of many academic publications. This is evidenced by the papers written by S. Goncharenko [5],E. Lodatko [12], O. Pochuieva [14], O. Shmyrko [17], M. Skrypnyk [18], N. Tonkonoh [20] and others. A number of leading scholars, including V. Bykov [2; 3], M. Kademiya [6; 8], K. Levkovsky [2], N. Lypchanko-Kovachyk [13], O. Ovcharuk [3], T. Pushkar [15], M. Zhaldak [21] and others researched problems related to the competent introduction of modern informational and computer technologies in the educational process. Of a particular scientific interest areacademic papers of British and European scholars on the researched problem. They are: C. Abbott [1], J. Davison [4],A. Hatherly [7], S. Kennewell [9], R. Kozma [10]. Their research reveals the importance of information flows from global networks for modern educational process.

S. Kennewell states that the term 'ICT' covers all aspects of computers, networks (including the Internet) and certain other devices with information storage and processing capacity such as smart phones and automatic control devices. The common factors here are that the devices process, store or communicate information, and that they are digital - that is, they handle information by representing it in terms of discrete symbols [9, p. 11]. The scholar distinguishes the following types of information-educational environment resources: CAD (computer-aided design), Data logging, Database, Desktop PC, Digital camera, Digital video, DTP (desktop publishing), E-mail, Encyclopedia, Graphic organizer, Internet, Intranet, Laptop PC, MIS (management information system), PDA (personal data assistant), Smart phone, Spreadsheet, Video games, VLE (virtual learning environment), WWW (World Wide Web).

According to J. Davison, the creation of the information environment of any substantive activity as a result of the development of informatization, information and telecommunication technologies leads to a radical rethinking of the goals, content, forms and methods of training specialists at a totally new level [4, p. 34].

M. Kademiya notes that the more diverse the information and educational environment is, the more effective the process of learning will be, taking into account individual opportunities of each participant of the process, his / her interests, inclinations, subjective experience accumulated in learning and real life. Therefore, in the opinion of scholars, the principal goal of creating a single information-educational environment in higher educational institutions is the maintenance of a successful intellectual and creative development of a personality including informational culture formation [8, p. 90].

According to A. Hatherly, the main tasks of creating the information and educational environment at the higher educational institutions are connected with the provision of fundamentally new opportunities for cognitive creative activity of a person. This can be achieved via modern information and technical equipment used in educational process. 
The information and educational environment promotes an increase in the efficiency and quality of the learning process; the intensification of the scientific research in higher educational institutions; time optimization and improving conditions for postgraduate and adult education; an increase in the management effectiveness of the separate educational institutions and the educational system in general; integration of national information educational systems into the global network, which greatly facilitates access to international information resources in the field of education, science, culture, etc. [7, p. 9].

Agreeing with researchers on the expediency of creating information-educational environment and the use of information technologies in the future foreign language teachers training, we consider it appropriate to analyze the views of leading scholars on the definition of the concept of "information-educational environment of higher educational institutions".

According to N. Lypchanko-Kovalchyk, the information environment of higher educational institutions is the constituent element of their activity, which includes organizational and methodological means, a set of technical and software tools for storage, processing, and transmission of information, provides operational access to information and enables educational scientific communication[13].

R. Kozma offers the following definition of the information-educational environment: it is a single information and educational space, built by integration of information in traditional and electronic media as well as computer telecommunication technologies. It may include virtual libraries, distributed databases, structured teaching aids and an expanded apparatus of didactics, in which the principles of a new pedagogical system operate [10, p. 118].

In the pedagogical dictionary edited by S. Goncharenkowe can find the following definition of the information-educational environment. It is a set of conditions that promote interaction between students, teacher and means of new information technologies, as well as the formation of cognitive activity of the student through the various types of educational computer hardware and software, teaching aids and the subject content of a particular course [5, p. 149-150].

According to O. Ovcharuk, the information-educational environment is a systematically organized set of means of data transmission, information resources, interactive protocols, hardware, and software, organizational and methodological support, aimed at satisfying the users' needs in information services and resources for the educational purposes [3, p. 12].

Effective information-educational environment opens up new possibilities in the educational process for all its participants and their interaction: reducing the time to search for and access to relevant educational and scientific information by teachers and students; acceleration of the educational content renovation(extra time for teachers to develop new educational and methodological literature); additional time for the students' individual work.

The purpose of the article is to reveal the expediency of creating and maintaining the information-educational environment of higher educational institutions; to analyze the views of scientists on the definition of "information-educational environment of higher educational institutions"; to characterize the information-educational environment of Khmelnytskyi National University; to reveal the peculiarities of the future foreign language teachers training in conditions of the information-educational environment of higher educational institutions; to theoretically substantiate the model of the future foreign language teachers training system in the conditions of the information-educational environment of higher educational institutions.

\section{FINDINGS}

Having analyzed the views of scholars, we can conclude that the informationeducational environment of higher educational institutions is a multi subjective and multidisciplinary system formation, which combines information and educational resources, 
computer teaching aids, means of managing the educational process, pedagogical techniques, methods and technologies and contributes to the formation of an intellectually developed, socially adapted creative person with an appropriate level of professional knowledge, skills and abilities. Organization of the information-educational environment requires extensive use of new IT technologies, multimedia learning tools, and upgraded laboratory facilities to study particular disciplines.

The information-educational environment of a higher educational institution performs the following functions: informational, providing open access to information and creating conditions for information exchange; interactive, which allows to implement internal system connections; communicative, allowing communication within "internal" as well as "external" information space; coordinating, creating and representing interaction between the content of different subjects; developmental, enabling intellectual growth and formation of personal creative qualities; professionally-oriented, focused on the profile of future professional activities. The introduction of the new information-educational environment in educational process is meant to move from individual projects to a systematic process that covers all activities. The new information-educational environment significantly enhances teachers' capabilities and optimizes management processes, thus forming technological competencies in a student that are crucial for our century.

In accordance with the stated purpose, it is necessary to characterize the informationeducational environment of Khmelnytskyi National University. The computerization and the implementation of a large number of software products and modern information technologies in the educational process enabled the creation of a developed computer network at the university. The university network develops within a single informational space model, based on information technologies. "The Educational Process Computerization" program is being implemented at the University. Its principal aim is to achieve a qualitatively new technological and organizational level of the educational process computerization, improvement of the management system and the quality of educational services through elearning environment. This network provides the functioning of information systems: distance learning, MOODLE, e-university, Planning and Finance Department Information System, Automated Library Information System (ALIS), Anti-plagiarism. The network links 46 computer laboratories and provides access to the university's information systems as well as to the World Wide Web. Additional software is currently being developed at the University in order to improve the existing information system, such as: electronic document management; electronic syllabus of an academic discipline; electronic information package of a course; tools for choosing elective disciplines by students; questionnaires about the quality of educational courses and the way they are taught.

One of the didactic components of the educational process is the electronic courses placed in the information-educational environment based on the MOODLE system (Modular Object-Oriented Dynamic Learning Environment). MOODLE provides the ability to design, create and manage information resources of an educational institution. MOODLE is a fairly flexible system, since teachers can independently create and manage an electronic course, control access to their courses, use time constraints, create their own knowledge assessment systems, monitor and check students' assignments. MOODLE allows educators, of any kind, to create a private space online, filled with tools that easily create courses and activities, all optimized for collaborative learning.

MOODLE provides convenient content management tools and various forms of class organization. According to the results of tasks performed by the students, the teacher can submit ratings and comment on students' works. Since the MOODLE system is focused on the possibility of being used in distance learning, it has a large set of communicational tools. MOODLE can be integrated with online content resource repositories, enterprise solutions for 
managing course registration, payment and enrolment, course schedules, training resources, compliance management and student or employee records. The facilities provided by the system enable the individual work of the teacher with each student. This is not just an email and an exchange of attachments, but also forums, chats, blogging, and more. You can use text, presentations, spreadsheets, charts, graphics, videos, and links on the Internet, auxiliary files and other materials.

Forums are intended to be used for the discussion among all participants of the educational process. Messages may include attachments, graphics, etc. A forum is easy to use for discussions and workshops. It provides an opportunity for the teacher to check the degree of mastering the necessary knowledge and skills on a specific topic.

Chat is an effective instrument of network communication that allows students to communicate in real time. Chats can be used as a training element for solving a certain creative task. At the same time, the assessment can be conducted both by the teacher and other students.

The glossary in the MOODLE system is an electronic counterpart to the special terms directory. The principal difference from the traditional vocabulary is that the glossary can be created consistently by students throughout the entire period of study that is why it is considered to be interactive. A student can provide his / her definition of a term and describe its properties by creating a mini-article. Other participants of the course have the opportunity to comment on this definition and propose their own.

The learning management system MOODLE has many functions that facilitate the knowledge assessment. Knowledge control is carried out with the help of a separate module offering various types of tests and providing the possibility of retesting, randomizing questions in the test tasks, organizing a database of questions. The system has mechanisms for keeping current assessments of each student, establishing a scale of assessments, automatic recalculation of test results, etc.

Training courses in the Modular Object-Oriented Dynamic Learning Environment include electronic course ware: electronic textbooks with the necessary theoretical material; glossaries, topics of lectures, seminars and workshops; samples of control questions; tasks and requirements for independent work; tasks for the final certification; description of the information tools and technologies necessary for carrying out educational tasks; methodological instructions; electronic test banks; summaries of lectures; Internet links for additional information resources; additional teaching materials (textbooks, manuals, journals, etc.).

Thus, MOODLE is a system for creating an information-educational environment of a higher educational institution focused primarily on providing interaction between the educational process participants via distance learning and supporting lifelong learning. Using MOODLE to train future foreign language teachers has a number of advantages, namely: the replacement of traditional educational forms and methods; the opportunity to study at any time convenient for students; free access to the set of necessary educational materials in electronic form; an innovative objective and independent system of knowledge assessment (electronic tests); an increase in creative and intellectual potential through self-organization, an ability to interact with peers, participating in forum and chat discussions.

The future foreign language teacher's readiness for professional activity depends on their main professional and personal characteristics. O. Shmyrkonotes that a modern foreign language teacher is a professional who received cultural, professional, psychological, pedagogical and methodological training during his / her education [17]. The result of the professional training of a future teacher is traditionally considered to be his / her willingness to engage in professional activities and the ability to use the latest forms, methods, techniques and innovative technologies. N. Tonkonoh states that the future foreign language teacher is, 
first of all, a psychologist who helps children to orientate themselves in the socially tense situation of the present [20]. In the conceptual principles of "The New Ukrainian School" it is emphasized that modern teachers are expected to adopt the learner-centered and competency approaches to management in the educational process, group dynamic psychology, etc. In this context, it makes sense to speak about a new role of the teacher - as a coach, facilitator, tutor, and moderator in child's individual educational trajectory, rather than only as a mentor and source of knowledge [19].

Therefore, by a model of foreign language teachers training system in the informationeducational environment, we mean the graphic reproduction of the specially organized interaction of teachers and students in the educational process of higher educational institutions. Our model of foreign language teachers training system aims at promoting and facilitating the process of research by solving the following tasks: to formulate a specific final goal for teachers and students; to control the effectiveness of the future foreign language teachers' training process; to specify the requirements of society for the knowledge, skills and personal qualities of the future foreign language teachers. Finally, it will help the students to understand the importance of professional activity in the process of their professional development. It will also help to intensify students' reflection and their focus on selfdevelopment.

Modeling and use of models are organically linked to forecasting. But a model does not only provide a forecast, but also makes it more complete on the basis of experience, expert assessments, and identified trends in the future, taking into account current challenges. The predictability of the model of the future foreign language teachers training system is determined by: taking into consideration not only current but also future needs of society, in particular the reflection of new prospective requirements for the future foreign language teachers training and trends in the educational system development; the formulation of the methodological support of the model (the main general didactic and specific principles of the organization of the future foreign language teachers training, methodological approaches, etc.); taking into account the structure of the future foreign language teachers' readiness for professional activity; achievement of flexibility and dynamism of the model, in accordance with the degree of preparation of the future foreign language teachers for professional activity; elucidation of organizational and pedagogical conditions that determine the methodology and technology of the future foreign language teachers training in accordance with the structure of readiness for professional activity; reproduction of the achievement of a certain result of training, which is represented by different levels and serves for continuous monitoring; taking into account the dynamics of changes not only at the level of components of readiness for the professional activity of the future foreign language teachers, but also the system as a whole.

The effective functioning of a model is possible if it meets the requirements for other participants in the simulation process, i.e. the inertia (relative to the environment in which it exists); sufficient consistency with the scientific environment in which it functions; simplicity (the simpler a model is, the closer to the simulated reality and more convenient it is for use); adequacy (relevance to the object);completeness, accuracy and objectivity of the model for the realization of the set goal.

Our model of the future foreign language teachers training system in higher educational institutions is an integral system. All its structural elements have their own functional purpose and influence each other, are in close interaction and are aimed at achieving the declared goal.

Consequently, the model of the training system contains the following blocks: target; theoretical and methodological; content and technological; control-productive.

Target block of the model defines the purpose of the future foreign language teachers training in conditions of the information-educational environment of higher education 
institutions. The principal purpose includes formation and development of innovative worldview, innovative style of scientific and pedagogical thinking, knowledge of and skills in psychology, pedagogy and linguistics, understanding of language system and the main linguistic and linguo-didactic categories, speech mechanisms, as well as the history, culture, modern problems of the country the language of which is studied. The future foreign language teachers have to be acquainted with the features of all components of educational process: the goals, methods, means and the content of the program for foreign language teaching and other official documents, the main provision of the didactic and methodological principles; the main requirements to the personality of a modern teacher, in particular to the level of his / her professional skills and social requirements for a competitive future foreign language teacher. The target block of the model is a core factor enabling the development of other elements of the model needed to achieve the expected result.

The theoretical and methodological block highlights the conceptual framework of the future foreign language teachers training; methodological approaches (systemic, competency based, axiological, cultural, activity, communicative, student-centered, interdisciplinary); general and specific principles of teaching (humanization, scientific, systematic and consistent, modular, accessibility and strength, combination of theory with practice, individualization, modeling of professional activity or functionality, innovation, taking into account interdisciplinary connections, sociocultural orientation, consciousness, activity and autonomy; communicative-oriented learning). Through the conceptual framework, the definition of methodological approaches and general didactic and specific principles of foreign language teachers training the theoretical and methodological block directly affects the structure and nature of the content and technological block of the model.

The content and technological block presents the organizational and pedagogical conditions, the description of the basic methods, forms, means and technologies of professional training. Organizational and pedagogical conditions of the future foreign language teachers training are the following:

1. The improvement of motivation for professional activity and formation of professional value orientations for future foreign language teachers through the use of interactive technologies.

2. The use of student-centered technologies in the process of the future foreign language teachers training.

3. The introduction of different types of practical training sessions and extra-curriculum work to gain experience in future professional activities.

4. The elaboration and support of educational and creative environment aimed at formation of future teachers' readiness for professional activity.

5. The development of the future foreign language teachers' professional reflection.

The content provision of the model is regulated by the Law of Ukraine "On Higher Education", the implementation of which is regulated by the State Standard of Higher Education, the Field Standard of Higher Education, curricula and syllabi of the major "014 Secondary Education. English Language and Literature" for Bachelor and Master Degrees. As a result of the curricula analysis, a block of educational disciplines has been identified. It has been proved that all of them directly or indirectly influence the process of the future foreign language teachers training.

Thus, in the cycle of the Humanities the following disciplines have been singled out: "The History of Ukraine", "The Ukrainian Language for Professional Purposes", "The History of Ukrainian Culture", "Philosophy", etc. The following courses have been included in the cycle of linguistic disciplines: "Introduction to Linguistics", "General Linguistics", "Stylistics", "Lexicology", "Theoretical Phonetics", "Theoretical Grammar", "History of the English Language", etc. The cycle of professional and practical disciplines includes: "General 
Psychology", "Developmental Psychology", "History of Pedagogy", "Fundamentals of Pedagogical Skills", "Pedagogy and Psychology of Higher Education", "Didactics", "Theory and Methodology of Education", "Social Psychology", "Practical Course of the English Language", "Practical Course of the Second Foreign Language (German)", "Practical Grammar of the German Language", "Practical Phonetics", "Practical Grammar of the English Language", etc. The disciplines "Modern Ukrainian Literary Language", "Educational Technologies", "Methodology of Educational Work in Summer Health Institutions", "New Technologies in Foreign Languages Teaching", "The Theory and Practice of Translation", "Theoretical Course of the Second Foreign Language" are the disciplines of free choice of educational institutions. The list of electives comprises: "Innovative Assessment Technologies in the Context of Student-Centered Learning", "Project Methodology of Foreign Language Teaching", "Business English", "Business German", "Modern German Grammar", "Fundamentals of Comparative Linguistics", "Linguistic Analysis of Literary Texts", "Comparative Typology", "Linguistic Studies (German language)", "Formal Discourse and Public Speaking", "Intercultural Communication", "Interpretation of Fiction", "Literature of England and the USA", "Comparative Professional Pedagogy", "Modern Linguistic Research", "Academic Writing", "Analytical Reading (German)", "Ukrainian Language for Science", etc.

Another component of the content support of the future foreign language teachers' training is the different types of internships at school, at the university and in summer camps.

Thus, the content support of the model includes: the cycle of the Humanities, the cycle of linguistic disciplines, the cycle of professional and practical disciplines, the cycle of disciplines of free choice of educational institution, the electives and different types of internship. Methods, tools, forms and learning technologies are the other component of the model of the future foreign language teachers training system.

The next block in the model of the future foreign language teachers training system in the conditions of the information-educational environment of higher educational institutions is the identification of stages of its implementation.

Theoretical and practical stage implies studying the Humanities, linguistic disciplines, professionally-oriented disciplines and practicums, disciplines of free choice of educational institution, electives. At this stage, the obtaining of thorough theoretical knowledge necessary in the further professional activity of the future foreign language teachers takes place. The theoretical and practical stage is aimed at reinforcement of the cognitive activity and value orientations of students through educational discussions, motivational trainings, workshops and practical training sessions, didactic role and business games, problem lectures, application of modern innovative and interactive methods, i.e.: project method, case-method, etc. and covers the first two years of study at the university.

Correction and stabilization stage envisages students' further mastering of the system of psychological, pedagogical, linguistic, methodological knowledge, professional techniques, modern innovative teaching technologies, professional disciplines; the formation of practical skills; the formation of positive motives, value orientations, the stimulation of cognitive activity and responsibility in learning and future professional activities. At this stage, the development of students' communicative skills, their professional and personal qualities, pedagogical abilities, formation of professionally oriented beliefs, attitudes and views on further pedagogical activity, control, analysis and evaluation of learning outcomes are observed. The levels of educational content mastering, as well as the levels of relevant skills formation are checked. Students take internship and are able to apply the acquired theoretical knowledge in practical work.

This stage covers the third and the fourth years of study at the university. Innovative forms of training are used at the correction and stabilization stage. Students are offered 
interactive seminars, lectures, workshops, discussions, round tables, "brainstorming", classes in the form of press conferences, educational excursions, role and business games, webquests, simulated communication situations that imitate the real conditions of professional activity. Moreover, the introduction of innovative forms of the educational process directs students towards research.

The reflexive and fixing stage of the model lasts during Master program. This stage is characterized by the formation of a system of linguistic, psychological, pedagogical and methodological knowledge about the peculiarities of the modern educational process, fluency in foreign languages, professional techniques and innovative teaching technologies, high level of the readiness for professional pedagogical activity. Special attention is paid to the internship at school and at the university in real conditions of professional activity. Thus, the third stage of the future foreign language teacher's training is characterized by strong practical component. The internships are aimed at encouraging students to find creative approaches to fulfilling the professional tasks; stimulating students' creative self-expression and introspection of the results of their professional activities; improving students' time management skills and individual career paths design abilities.

The control-productive block determines the formation of components that ensure the readiness of the future foreign language teachers for professional activity: (motivational and axiological, cognitive and communicative, pragmatic and practical, functional and personal, evaluative and reflexive) criteria (motivational, educational, operational, personal, reflexive) and levels (low (reproductive), middle (productive) or high (professional)).

As a result the following model of the future foreign language teachers training system in the conditions of the information-educational environment of higher educational institutions has been created (Figure 1).

\section{CONCLUSIONS AND PROSPECTS FOR FURTHER RESEARCH}

The expediency of creating and maintaining information-educational environment of higher educational institutions is determined by a number of factors: increasing the speed of information and knowledge transfer; the need for dynamic adaptation of students and specialists to the environment and the social changes that take place in it; the need to reform educational systems in accordance with the requirements of the information society (increasing productivity, transparency and flexibility of educational processes, training in accordance with the needs and abilities of students). Electronic educational resources and the information-educational environment created on their basis have considerable potential for improving the quality of the future foreign language teachers training. They promote students' awareness of the specifics of their future professional activities, develop personal and professional qualities necessary for their successful career; facilitate construction of individual educational paths, develop students' creative abilities. Using the simulation method gave an opportunity to create a model of the future foreign language teachers training system in the conditions of the information-educational environment of higher educational institutions. The developed model is characterized by integrity, all its blocks are interconnected, have a certain content, are aimed at the final result, i.e. the positive dynamics of the future foreign language teachers' readiness for professional activity. We see prospects of further investigation in the substantiation of the organizational and pedagogical conditions of the future foreign language teachers training in the conditions of the informationeducational environment of higher educational institutions. 


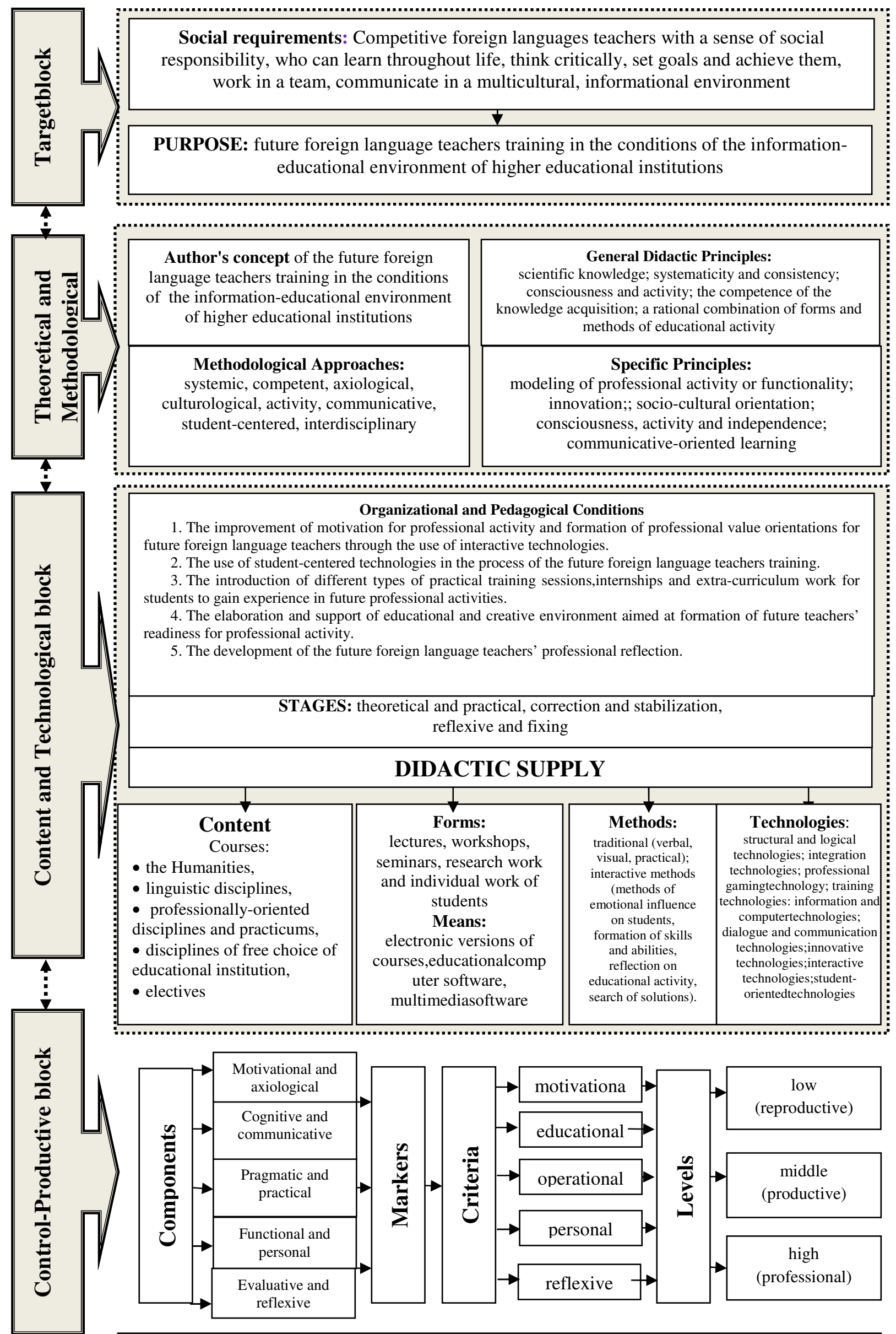

RESULT:positive dynamics in the formation of the future foreign languages teachers' readiness for professional activity 


\section{REFERENCES (TRANSLATED AND TRANSLITERATED)}

[1] C. Abbott, ICT: Changing Education :RoutledgeFalmer, 2001, pp. 21-25. (in English)

[2] V. Yu. Bykov,K. M.Levkovsky, Didactic and organizational-methodical problems of implementing the principles of education. Kyiv, 1994, pp. 17-19.(in Ukrainian)

[3] V. Yu. Bykov, O. V Ovcharuk, Assessment of information and communication competence of students and teachers in the conditions of European integration processes in education. Kyiv : Pedagogical Thought, 2017, pp. 12-14. (in Ukrainian)

[4] J. Davison, Debates in English Teaching : Routledge, 2011, pp.34-38. (in English)

[5] S. U. Goncharenko, Didactic Concept of Educational Content, Problems and prospects of the formation of the national humanitarian and technical elite, Part 1.Kharkiv: NTU-KPHI, 2002, pp. 149150.(inUkrainian)

[6] R. S. Gurevich, M. Yu. Kademiya, M. M. Kozyar, Information and communication technologies in the professional education of future specialists. Lviv : SPOLOM, 2012, pp. 10-11.(inUkrainian)

[7] A. Hatherly, 'ICT and the Greatest Technology: A Teacher's Mind',Early Childhood Folio, vol. 13, pp. 710, 2009. (in English)

[8] M. Yu. Kademiya, 'Pedagogical conditions of informatization of educational process in vocational schools', vol. 2, n. 90. Kielce, pp. 88-94, 2004.(in Ukrainian)

[9] S. Kennewell, Meeting the Standards in Using ICT for Secondary Teaching :RoutledgeFalmer, $2004, \mathrm{pp}$. 11-13. (in English)

[10] R. Kozma, 'Technology, Innovation, and Educational Change: A Global Perspective : A Report of the Second Information Technology in Education Study', International Society for Technology in Education, pp. 118-120, 2003.(in English)

[11] Law "On Education" [Online]. Available: https://zakon.rada.gov.ua/laws/show/2145-19. Accessed on: Oct. 2, 2018. (in Ukrainian)

[12] E. O. Lodatko, 'Modeling in pedagogy: reference points', Pedagogical science: history, theory, practice, trends of development, E-magazine, vol. 1, pp. 5-9, 2010. [Online]. Available: http://intellectinvest.org.ua/pedagog_editions_e-magazine. Accessed on: Oct. 23, 2018].(in Ukrainian)

[13] N. O. Lypchanko-Kovalchyk, 'The future Bachelors in Philology training to the development of interactive technology in professional activity'. [Online]. Available: http://ep3.nuwm.edu.ua/4031/1/\%D0\%94\%D0\%B8\%D1\%81\%D0\%B5\%D1\%80\%D1\%82\%D0\%B0 $\% \mathrm{D} 1 \% 86 \% \mathrm{D} 1 \% 96 \% \mathrm{D} 1 \% 8 \mathrm{~F} \% 20 \% \mathrm{D} 0 \% 9 \mathrm{~B} \% \mathrm{D} 0 \% \mathrm{~B} 8 \% \mathrm{D} 0 \% \mathrm{BF} \% \mathrm{D} 1 \% 87 \% \mathrm{D} 0 \% \mathrm{~B} 0 \% \mathrm{D} 0 \% \mathrm{BD} \% \mathrm{D} 0 \% \mathrm{BA}$ $\% \mathrm{D} 0 \% \mathrm{BE}-\% \mathrm{D} 0 \% 9 \mathrm{~A} \% \mathrm{D} 0 \% \mathrm{BE} \% \mathrm{D} 0 \% \mathrm{~B} 2 \% \mathrm{D} 0 \% \mathrm{~B} 0 \% \mathrm{D} 1 \% 87 \% \mathrm{D} 0 \% \mathrm{~B} 8 \% \mathrm{D} 0 \% \mathrm{BA} \% 20 \% \mathrm{D} 0 \% 9 \mathrm{E}$ .\%D0\%92.\%20\%D0\%B7\%D0\%B0\%D1\%85.pdf . Accessed on: Oct. 10, 2018].(in Ukrainian)

[14] O. O. Pochuieva, 'Modeling in the theory of educational processes management.'[Online]. Available: http://virtkafedra.ucoz.ua/el_gurnal/pages/vyp10/Pochueva.pdf . Accessed on: Oct. 5,2018]. (in Ukrainian)

[15] T. M. Pushkar, 'Formation of the future teachers of philological specialties readiness for interpersonal interaction by means of communication technologies.'[Online]. Available: http://www.uk.Xpdf.ru/5pedagogika/ 2275363-11-udk-378-39713-7-pravah-rukopisu-pushkar-tetyana-mikolaivnaformuvannya-gotovnosti-maybutnih-uchiteliv-filologichni.php. Accessed on: Oct. 1,2018].(in Ukrainian)

[16] T. M. Pushkar, 'Modeling as a Theoretical Method for the Development of Pedagogical Technology for the Training of Teachers of the Philological Profile. Makarenko's approaches to pedagogical modeling.' [Online]. Available: http://eprints.zu.edu.ua/11023/1/13ptmmyt.pdf . Accessed on: Oct. 1, 2018].(in Ukrainian)

[17] O. S. Shmyrko, 'Pedagogical conditions of professional development of future foreign languages teachers in the system of university pedagogical education.'[Online]. Available: http://www.khnu.km.ua/root/res/2-25-47-10.pdf . Accessed on: Oct. 11, 2018].(in Ukrainian)

[18] M. I. Skrypnyk, Training of scientific and pedagogical staff, graduate students and applicants: modernization of the training process in the system of postgraduate education. Kyiv : Education Management University, 2014,151 p. (in Ukrainian)

[19] The New Ukrainian School. Conceptual Principles of Secondary School Reform [Online]. Available: https://mon.gov.ua/storage/app/media/zagalna\%20serednya/Book-ENG.pdf. Accessed on: Oct. 5, 2018] (in English)

[20] N. I. Tonkonoh, 'Formation of an individual strategy of educational and professional activity for the future foreign languages teachers.'[Online]. Available: https://phdpu.edu.ua/images/\%D0\%92\%D1\%87\%D0\%B5\%D0\%BD\%D0\%B0_\%D1\%80\%D0\%B0\%D0 \%B4\%D0\%B0_\%D0\%9A_27.053.03/7032018/\%D0\%B4\%D0\%B8\%D1\%81\%D0\%B5\%D1\%80\%20\% 
D0\%A2\%D0\%BE\%D0\%BD\%D0\%BA\%D0\%BE\%D0\%BD\%D0\%BE\%D0\%B3.pdf. Accessed on: Oct. 2, 2018]. (inUkrainian)

[21] M. I. Zhaldak, 'Computer-oriented systems of teaching in general secondary schools',Scientific papers ofUman State Pedagogical University named after PavloTychyna, vol. 2, pp. 144-152, 2008.(in Ukrainian)

\title{
МОДЕЛЬ СИСТЕМИ ПІДГОТОВКИ МАЙБУТНІХ УЧИТЕЛІВ ІНОЗЕМНОЇ МОВИ ДО ПРОФЕСІЙНОЇ ДІЯЛЬНОСТІ В УМОВАХ ІНФОРМАЦІЙНО- ОСВІТНЬОГО СЕРЕДОВИЩА ЗАКЛАДІВ ВИЩОЇ ОСВІТИ
}

\author{
Гуревич Роман Семенович \\ доктор педагогічних наук, професор, дійсний член (академік) НАПН України, академік АНВО України, \\ директор Навчально-наукового інституту педагогіки, психології, підготовки фахівців вищої кваліфікації \\ Вінницький державний педагогічний університет імені Михайла Коцюбинського, м. Вінниця Україна \\ ORCID ID 0000-0003-1304-3870 \\ imadvdpu@gmail.com
}

\section{Рогульська Оксана Олександрівна}

кандидат педагогічних наук, доцент, доцент кафедри практики іноземної мови та методики викладання Хмельницький національний університет, м. Хмельницький Україна

ORCID ID 0000-0001-5603-0274

oxana.rogulska@gmail.com

\section{Тарасова Ольга Володимирівна}

кандидат педагогічних наук, доцент кафедри практики іноземної мови та методики викладання Хмельницький національний університет, м. Хмельницький Україна

ORCID ID 0000-0001-8574-6466

tarasova20olia@gmail.com

\section{Магдюк Ольга Вікторівна}

кандидат педагогічних наук, доцент кафедри практики іноземної мови та методики викладання Хмельницький національний університет, м. Хмельницький Україна ORCID ID 0000-0001-6165-6386

olga-tychinska@rambler.ru

Анотація. У статті розкрито доцільність створення та підтримки інформаційно-освітнього середовища закладів вищої освіти та проаналізовано погляди науковців щодо визначення поняття «інформаційно-освітне середовище закладів вищої освіти»; схарактеризовано інформаційно-освітне середовище Хмельницького національного університету та розкрито особливості підготовки майбутніх учителів іноземної мови в умовах інформаційноосвітнього середовища закладів вищої освіти. Доведено, що інформаційно-освітнє середовище має чималий потенціал для підвищення якості навчання майбутніх учителів іноземних мов та сприяє усвідомленню студентами особливостей майбутньої професійної діяльності, розвитку особистісних та професійно важливих якостей студентів, необхідних для успішного опанування майбутньої професії; побудові індивідуальних освітніх траєкторій; розвитку творчих здібностей. У статті теоретично обгрунтовано модель системи підготовки майбутніх учителів іноземної мови в умовах інформаційно-освітнього середовища закладів вищої освіти. Модель містить такі блоки: цільовий, теоретикометодологічний, змістово-технологічний, контрольно-результативний. Цільовий блок моделі розкриває мету підготовки майбутнього вчителя іноземної мови і є системотвірним чинником, що продукує інші елементи моделі, необхідні для досягнення очікуваного результату. Теоретико-методологічний блок охоплює основні положення концепції підготовки майбутніх викладачів іноземної мови до професійної діяльності; методологічні підходи, загальнодидактичні й специфічні принципи. Змістово-технологічний блок уміщує організаційно-педагогічні умови, характеристику основних методів, форм професійної підготовки, засобів та технологій ііі здійснення. Контрольно-результативний блок визначає сформованість компонентів, що забезпечують готовність майбутніх учителів іноземної 
мови до професійної діяльності: (мотиваційно-ціннісного, когнітивно-комунікативного, діяльнісно-практичного, професійно-особистісного, оцінно-рефлексивного); критерії (мотиваційний, знаннєвий, операційний, особистісний, рефлексивний) і рівні (низький (репродуктивний), середній (продуктивний) чи високий (професійний)). Розроблена модель системи підготовки майбутніх учителів іноземної мови до професійної діяльності $\epsilon$ цілісною системою, всі структурні елементи якої мають власне функціональне призначення, впливають один на одного, перебувають у тісній взаємодії та спрямовані на досягнення заявленої мети.

Ключові слова: підготовка майбутніх учителів іноземних мов; електронні освітні ресурси; інформаційно-освітнє середовище; вищі навчальні заклади; модель системи.

\title{
МОДЕЛЬ СИСТЕМЫ ПОДГОТОВКИ БУДУЩИХ УЧИТЕЛЕЙ ИНОСТРАННОГО ЯЗЫКА К ПРОФЕССИОНАЛЬНОЙ ДЕЯТЕЛЬНОСТИ В УСЛОВИЯХ ИНФОРМАЦИОННО-ОБРАЗОВАТЕЛЬНОЙ СРЕДЫ УЧРЕЖДЕНИЙ ВЫСШЕГО ОБРАЗОВАНИЯ
}

\author{
Гуревич Роман Семенович \\ АНВО Украины, директор Учебно-научного института педагогики, психологии, подготовки \\ специалистов высшей квалификации \\ Украина \\ ORCID ID 0000-0003-1304-3870 \\ imadvdpu@gmail.com \\ Рогульская Оксана Александровна \\ кандидат педагогических наук, доцент, \\ доцент кафедры практики иностранного языка и методики преподавания \\ Хмельницкий национальный университет , г. Хмельницкий, Украина \\ ORCID ID 0000-0001-5603-0274 \\ oxana.rogulska@gmail.com
}

доктор педагогических наук, профессор, действительный член (академик) НАПН Украины, академик

Винницкий государственный педагогический университет имени Михаила Коцюбинского, г. Винница,

\section{Тарасова Ольга Владимировна}

кандидат педагогических наук, доцент кафедры практики иностранного языка и методики преподавания Хмельницкий национальный университет, г. Хмельницкий, Украина

ORCID ID 0000-0001-8574-6466

tarasova20olia@gmail.com

\section{Магдюк Ольга Викторовна}

кандидат педагогических наук, доцент кафедры практики иностранного языка и методики преподавания Хмельницкий национальный университет, г. Хмельницкий, Украина

ORCID ID 0000-0001-6165-6386

olga-tychinska@rambler.ru

\begin{abstract}
Аннотация. В статье раскрыта целесообразность создания и поддержки информационнообразовательной среды учреждений высшего образования и проанализированы взгляды ученых относительно определения понятия «информационно-образовательная среда высших учебных заведений»; охарактеризована информационно-образовательная среда Хмельницкого национального университета и раскрыты особенности подготовки будущих учителей иностранных языков в условиях информационно-образовательной среды учреждений высшего образования. Доказано, что информационно-образовательная среда обладает немалым потенциалом для повышения качества обучения будущих учителей иностранных языков и способствует осознанию студентами особенностей будущей профессиональной деятельности, развитию личностных и профессионально важных качеств, а также творческих способностей студентов, необходимых для успешного овладения будущей профессией; построению индивидуальных образовательных траекторий. В статье теоретически обоснована модель системы подготовки будущих учителей иностранных языков в условиях информационно-образовательной среды
\end{abstract}


учреждений высшего образования. Модель содержит следующие блоки: целевой, теоретико-методологический, содержательно-технологический, контрольнорезультативный. Целевой блок модели раскрывает цель подготовки будущего учителя иностранного языка и является системообразующим фактором, производит другие элементы модели, необходимые для достижения ожидаемого результата. Теоретикометодологический блок представлен концепциями подготовки будущих учителей иностранного языка к профессиональной деятельности; методологические подходы, общедидактические и специфические принципы. Содержательно-технологический блок представлен организационно-педагогическими условиями, характеристикой основных методов, форм профессиональной подготовки, средств и технологий ее осуществления. Контрольно-результативный блок определяет сформированность компонентов, обеспечивающих готовность будущих учителей иностранных языков к профессиональной деятельности: (мотивационно-ценностного, когнитивно-коммуникативного, деятельнопрактического, профессионально-личностного, оценочно-рефлексивного); критерии (мотивационный, операционный, личностный, рефлексивный) и уровни (низкий (репродуктивный), средний (продуктивный) или высокий (профессиональный)). Разработанная модель системы подготовки будущих учителей иностранных языков к профессиональной деятельности является целостной системой, все структурные элементы которой имеют собственное функциональное назначение, влияют друг на друга, находятся в тесном взаимодействии и направлены на достижение заявленной цели.

Ключевые слова: подготовка будущих учителей иностранных языков; электронные образовательные ресурсы; информационно-образовательная среда; высшие учебные заведения; модель системы.

\section{(cc) EY-NC-SA}

This work is licensed under Creative Commons Attribution-NonCommercial-ShareAlike 4.0 International License. 